\title{
Double Cyclometalation via Carbon-Silicon Bond Cleavage by Palladium(II) Acetate. X-ray Structure of a Cationic 1,4-Dipalladated Benzene Ring and Selective Synthesis of Heterobimetallic 1,4-Phenylene-Bridged Platinum(II)-Palladium(II) Complexes
}

\author{
Pablo Steenwinkel, ${ }^{\dagger}$ Stuart L. J ames, ${ }^{\dagger}$ David M. Grove, ${ }^{\dagger}$ Huub Kooijman, ${ }^{\ddagger}$ \\ Anthony L. Spek, ${ }^{\ddagger}$, and Gerard van Koten $*, \dagger$ \\ Debye Institute, Department of Metal-Mediated Synthesis, Utrecht University, Padualaan 8, \\ $3584 \mathrm{CH}$ Utrecht, The Netherlands, and Bijvoet Center for Biomolecular Research, \\ Department of Crystal and Structural Chemistry, Utrecht University, Padualaan 8, \\ $3584 \mathrm{CH}$ Utrecht, The Netherlands
}

Received November 6, $1996^{\otimes}$

Summary: The disilylated compound 1,4-bis(trimethylsilyl)-2,3,5,6-tetrakis((dimethylamino)methyl)benzene, $\left(\mathrm{Me} \mathrm{Si}_{2} \mathrm{C}_{2} \mathrm{~N}_{4}\right.$, 4, can be ectrophilically palladated selectively at the $\mathrm{C}-\mathrm{Si}$ bonds to afford the neutral 1,4bis(palladium) complex $\left[(\mathrm{AcOPd})_{2}\left(\mathrm{C}_{2} \mathrm{~N}_{4}\right)\right]$, from which the dicationic $\left[(\mathrm{LPd})_{2}\left(\mathrm{C}_{2} \mathrm{~N}_{4}\right)\right]^{2+}(\mathrm{L}=\mathrm{MeCN})$ organome tallic species are accessible The monosilylated species $\left(\mathrm{Me} \mathrm{S}_{3} \mathrm{Si}\right)(\mathrm{H}) \mathrm{C}_{2} \mathrm{~N}_{4}, \mathbf{5}$, can be used for the preparation of the dicationic heterodinuclear platinum(II)-palladium(II) species $\left[(\mathrm{LPd})(\mathrm{LPt})\left(\mathrm{C}_{2} \mathrm{~N}_{4}\right)\right]^{2+}(\mathrm{L}=\mathrm{MeCN})$ via a sequence of transmetalation of the organol ithium derivative of $\mathbf{5}$ with $\left[\mathrm{PtCl}_{2}\left(\mathrm{SEt}_{2}\right)_{2}\right]$, followed by a $\mathrm{C}-\mathrm{Si}$ bond palladation reaction.

Much interest exists in homo- and heterobimetallic complexes in which the metal centers are connected via a short carbon chain, ${ }^{1}$ and one reason for this is that these systems may function as building blocks for organometallic polymers. However, one of the most intriguing aspects of such bimetallic systems is the electronic contact created when a $\pi$-conjugated group is used to separate the metal centers. For example, the ol igophenylene-bridged bis(ruthenium) complexes $\mathbf{1}$ and 2 (Figure 1) exhibit very high comproportionation constants, and in $\mathbf{2}$ it has been found that an increase in distance between the metal centers results in a decrease in el ectronic communication. ${ }^{1}$

We have explored the synthesis of linear multimetallic systems using $\pi$-conjugated bridging ligands containing $\mathrm{N}, \mathrm{C}, \mathrm{N}^{\prime}$ and related coordination motifs. Our basis for this exploration is the anionic ligand $\left\{\mathrm{C}_{6} \mathrm{H}_{3}\left(\mathrm{CH}_{2}-\right.\right.$ $\left.\left.\mathrm{NMe}_{2}\right)_{2}-2,6\right\}^{-}$, which has been shown to be capable of adopting several different coordination modes. The investigation of organometallic complexes of this ligand has enabled us to study mechanistic aspects and reaction intermediates of metal-mediated and -catalyzed reactions. $^{2}$

* To whom correspondence should be addressed. E-mail: vankoten@xray.chem.ruu.nl.

† Debye Institute.

₹ Bijvoet Center for Biomolecular Research.

$\S$ Address correspondence pertaining to crystallographic studies to this author. E-mail: spea@xray.chem.ruu.nl.

${ }^{\otimes}$ Abstract published in Advance ACS Abstracts, J anuary 15, 1997.

(1) (a) Sutter, J .-P.; Grove, D. M.; Beley, M.; Collin, J .-P.; Veldman, N.; Spek, A. L.; Sauvage, J .-P.; van Koten, G. Angew. Chem., Int. Ed. Engl. 1994, 33, 1282. (b) Beley, M.; Chodorowski, S.; Collin, J .-P.; Sauvage, J .-P. Tetrahedron Lett. 1993, 34, 2933.

(2) van Koten, G. Pure Appl. Chem. 1989, 61, 1681 and references therein.
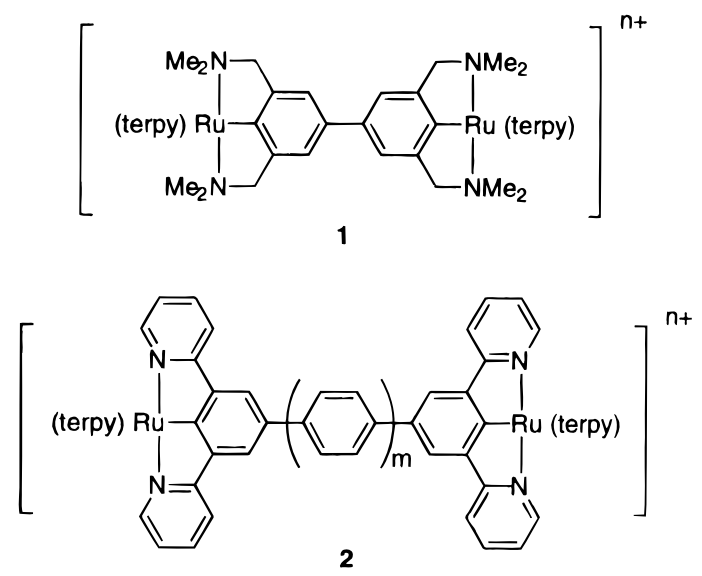

Figure 1. Structures of bis(ruthenium) complexes $\mathbf{1}$ and 2 with a high degree of electronic communication (terpy = $2,2^{\prime} ; 2^{\prime \prime}, 6^{\prime}$-terpyridine; $\mathrm{n}=2,3,4, ; \mathrm{m}=0,1,2$ ).

Our approach here is to prepare the shortest possible aromatic spacer containing two $\mathrm{N}, \mathrm{C}, \mathrm{N}^{\prime}$-coordination moieties. This is the 1,4-monophenylene bridge, $\left[\mathrm{C}_{6}\left(\mathrm{CH}_{2}-\right.\right.$ $\left.\left.\mathrm{NMe}_{2}\right)_{4}-2,3,5,6\right]^{2-}$ (a dianionic ligand derived from $\mathrm{C}_{6} \mathrm{H}_{2}\left(\mathrm{CH}_{2} \mathrm{NMe}_{2}\right)_{4}-1,2,4,5$, 3; see Scheme 1), ${ }^{3}$ that could be anticipated to provide bimetallic complexes in which there would be a higher intermetallic electronic contact than in either $\mathbf{1}$ or $\mathbf{2}$. Moreover, this chosen system contains tertiary amine groups that provide chelating intramolecular coordination to the metal centers, and as a result electron delocalization will be concentrated in the 1,4-phenylenediyl system.

It is clear that our goal of preparing heterobimetallic complexes is not straightforward and is likely to involve the selective introduction of two different metal centers in two separate synthetic sequences. We now report the successful selective syntheses of 1,4-phenylene $\left(=\mathrm{C}_{2} \mathrm{~N}_{4}\right)$ bridged bis(palladium(II)) complexes 6-8, as well as of heterodinuclear platinum(II)-pal ladium(II) complexes 10-12. The applied strategies involve combinations of transmetalation ${ }^{4}$ and newly developed $\mathrm{C}-\mathrm{Si}$ bond palladation reactions. ${ }^{5}$ This approach was found to be necessary since direct cyclometalation routes, which have been reported for the preparation of monometall ic $c^{6 a, b}$

(3) A sulfur-containing anal og of 3, i.e. $\left.\mathrm{C}_{6} \mathrm{H}_{2}\left(\mathrm{CH}_{2} \mathrm{SPh}\right)_{4}\right)-1,2,4,5$, has been cyclometalated to afford a monophenylene-bridged bis(palladium) complex: Loeb, S.J .; Shimizu, G. K. H.J . Chem. Soc., Chem. Commun. 1993, 1395 
Scheme 1. Synthesis and Subsequent Metalation Reactions of 4 and 5 Yielding Neutral and Cationic Dipalladium(II) and Heterobimetallic Platinum(II)-Palladium(II) Complexes 6-8 and 10-12a

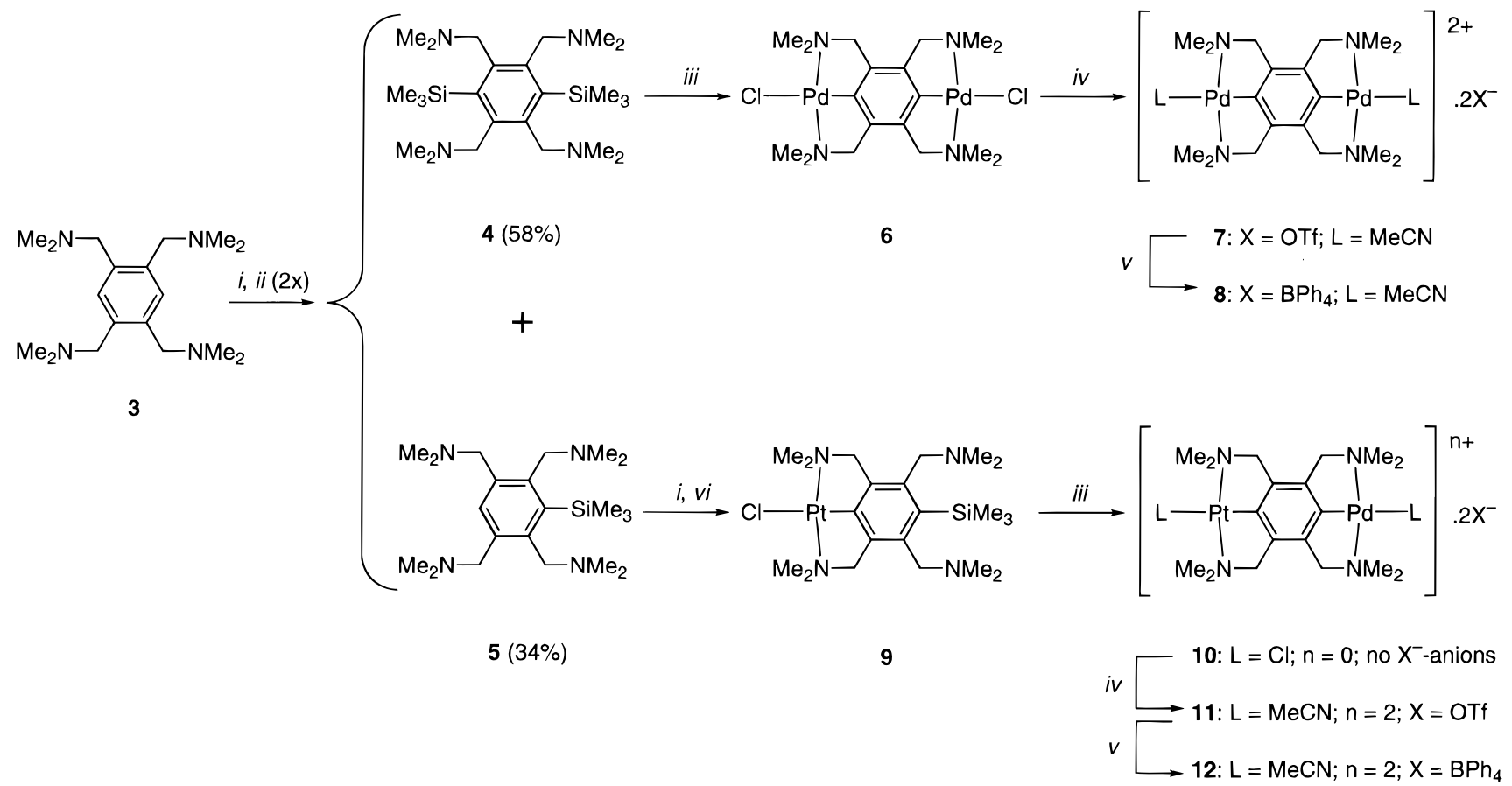

a Key: i, n-BuLi, hexane, room temperature, $18 \mathrm{~h}$; ii, MesSiOTf, THF, room temperature, $5 \mathrm{~min}$; $\mathrm{iii}, \mathrm{Pd}(\mathrm{OAc})_{2}, \mathrm{MeOH}(18 \mathrm{~h})$ and $\mathrm{LiCl}, \mathrm{MeOH}$, room temperature, $15 \mathrm{~min}$; iv, AgOTf, $\mathrm{MeCN}$, room temperature, 20 min; $v, \mathrm{NaBPh}_{4}, \mathrm{MeCN}$, room temperature, $5 \mathrm{~min}$; vi, $\left[\mathrm{PtCl}_{2}\left(\mathrm{SEt}_{2}\right)_{2}\right], \mathrm{THF}$, room temperature, $3 \mathrm{~h}$.

and bimetallic arylpalladium compounds, $3,6 \mathrm{c}$ are not yet available for tetraamine $\mathbf{3}$.

Starting from $3,{ }^{7}$ the route to bis(palladium) complexes proceeds via the disilylated compound $\mathbf{4}$, whereas the route to heterobi metallic species proceeds via monosilylated compound $\mathbf{5}$. Compounds $\mathbf{4}$ and $\mathbf{5}$ have been prepared as a mixture from two successive monol ithiation/silylation cycles employing $\mathbf{3}$ as a substrate with n-BuLi and $\mathrm{Me}_{3} \mathrm{SiOTf}$ (OTf = trifluoromethanesulfonate) as the reagents; subsequent column chromatographic separation affords pure $\mathbf{4}$ and $\mathbf{5}$, which have been fully characterized (NMR, el emental microanalysis, X-ray of 4). ${ }^{8}$

Compound 4 reacts with $\mathrm{Pd}(\mathrm{OAC})_{2}$ in a direct $\mathrm{C}-\mathrm{Si}$ bond cleavage reaction to afford, after addition of $\mathrm{LiCl}$, the bis(palladium(II)) complex $\left[(\mathrm{PdCl})_{2} \mathrm{C}_{2} \mathrm{~N}_{4}\right], 6$, as a white solid in $78 \%$ yield (Scheme 1). Complex 6 has poor solubility characteristics and was converted into the ionic derivative $\mathbf{7}$ using silver triflate and precipitated as its tetraphenylborate salt $\mathbf{8} .^{9}$ Recrystall ization of $\mathbf{8}$ from hot acetonitrile gave crystals that were

(4) (a) de Koster, A.; Kanters, J . A.; Spek, A. L.; van der Zeijden, A. A. H.; van Koten, G.; Vrieze, K. Acta Crystallogr. 1985, C41, 893. (b) Abbenhuis, H. C. L.; Feiken, N.; Grove, D. M.; J astrzebski, J . T. B. H.; Kooijman, H.; van der Sluis, P.; Smeets, W. J . J .; Spek, A. L.; van Koten, G. J . Am. Chem. Soc. 1992, 114, 9773.

(5) (a) Eaborn, C. J . Organomet. Chem. 1975, 100, 43. (b) Fleming, I. In Comprehensive Organic Chemistry; Barton, D., Ollis, W. D., Eds.; Pergamon: Oxford, U.K., 1979; Vol. 3, p 618. (c) Valk, J.-M.; van Belzen, R.; Boersma, J .; Spek, A. L.; van Koten, G. J. Chem. Soc., Dalton Trans. 1994, 2293.

(6) (a) Ryabov, A. D.; van Eldik, R. Angew. Chem., Int. Ed. Engl. 1994, 33, 783. (b) Valk, J.-M.; van Belzen, R.; Boersma, J .; Spek, A. L.; van Koten, G. J . Chem. Soc., Dalton Trans. 1994, 2293. (c) Trofimenko, S. I norg. Chem. 1973, 12, 1215.

(7) Van der Zeijden, A. A. H.; van Koten, G. Recl. Trav. Chim. PaysBas 1988, 107, 431.

(8) Steenwinkel, P.; Deelman, B.-J .; J astrzebski, J . B. T. H., Grove, D. M.; Kooijman, H.; Spek, A. L.; van Koten, G. Manuscript in preparation.

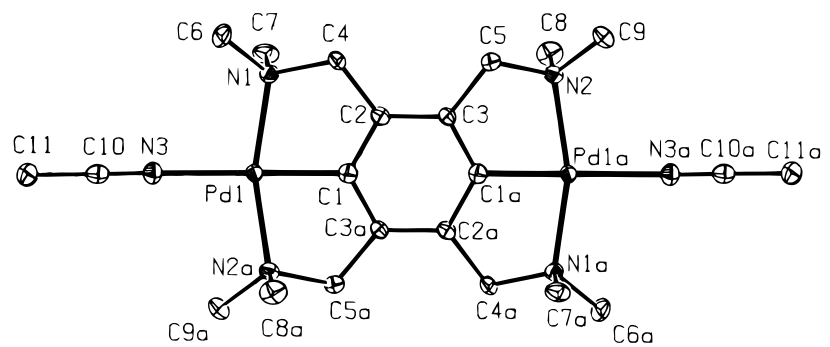

Figure 2. ORTEP drawing ( $50 \%$ probability level) of the dication of 8. Hydrogen atoms, tetraphenylborate anions, and acetonitrile solvate molecules are omitted for clarity.

suitable for X-ray analysis, and the molecular geometry of $\mathbf{8}$ is shown in Figure 2. ${ }^{10}$ The $\mathrm{Pd}$-phenylene-Pd unit is planar with a Pd $\cdots P d$ distance of 6.5474(9) $\AA$ across the central metalated ring. Coordination of the orthoamine arms to the palladium centers affords $C_{2}$ symmetry related pairs of puckered five-membered rings, in which the N-donor atoms are lifted 19.9(3) and $-21.2(3)^{\circ}$ out of the plane of the bimetalated ring $(\mathrm{C}(2)-$ $\mathrm{C}(3)-\mathrm{C}(5)-\mathrm{N}(2)=-160.1(3)^{\circ}$ and $\mathrm{C}(3)-\mathrm{C}(2)-\mathrm{C}(4)-$

(9) ${ }^{1} \mathrm{H}$ NMR data for $7\left(\mathrm{CD}_{3} \mathrm{CN}, 200 \mathrm{MHz}\right): \delta 3.87\left(\mathrm{~s}, 8 \mathrm{H}, \mathrm{CH}_{2}\right)$, $2.80\left(\mathrm{~s}, 24 \mathrm{H}, \mathrm{NMe}_{2}\right) .{ }^{13} \mathrm{C} \mathrm{NMR}$ data for $7\left(\mathrm{CD}_{3} \mathrm{CN}, 50 \mathrm{MHz}\right): \delta 153.1$, 139.4 (Ar), $72.9\left(\mathrm{CH}_{2}\right), 53.4\left(\mathrm{NMe}_{2}\right)$.

(10) Crystal data for 8, $\left[\mathrm{C}_{22} \mathrm{H}_{38} \mathrm{~N}_{6} \mathrm{Pd}_{2}\right]\left[\mathrm{C}_{24} \mathrm{H}_{20} \mathrm{~B}\right]_{2}\left[\mathrm{C}_{2} \mathrm{H}_{3} \mathrm{~N}\right]_{2}: \mathrm{Mr}_{\mathrm{r}}=$ 1320 , colorless, crystal $(0.08 \times 0.10 \times 0.60 \mathrm{~mm})$, triclinic, space group $\mathrm{P} \overline{1}$ (No. 2) with $\mathrm{a}=10.2037(12) \AA, b=11.4148(11) \AA, c=15.368(2) \AA$ $\alpha=86.982(10)^{\circ}, \beta=81.848(11)^{\circ}, \gamma=68.900(9)^{\circ}, V=1653.1(3) \AA^{3}, Z$ $=1, D_{x}=1.326 \mathrm{~g} \mathrm{~cm}^{-1}, \mathrm{~F}(000)=686, \mu(\operatorname{MoK} \alpha)=5.9 \mathrm{~cm}^{-1}, 10530$ reflections measured, 7572 independent, $R_{\text {int }}=0.077\left(1.3^{\circ}<\theta<27.5^{\circ}\right.$, $\omega \mathrm{scan}, \mathrm{T}=150 \mathrm{~K}$, Mo K $\alpha$ radiation, graphite monochromator, $\lambda=$ $0.71073 \AA$ ) on an Enraf-Nonius CAD4-T diffractometer on rotating anode. The structure was solved by automated Patterson methods (DIRDIF 92). Refinement on $\mathrm{F}^{2}$ was carried out by full-matrix leastsquares techniques (SHELXL-93); no observance criterion was applied during refinement. Refinement converged at a final wR2 value of $0.1010, \mathrm{R} 1=0.0437$ (for 6109 reflections with $\mathrm{F}_{\mathrm{o}}>4 \sigma\left(\mathrm{F}_{\mathrm{o}}\right)$ ), and $\mathrm{S}=$ 1.02 , for 394 parameters. $\mathrm{H}$ atoms were placed on calculated positions riding on their carrier atom. A final difference Fourier showed no residual density outside -0.69 and 0.79 e $\AA^{-3}$. 
$\left.\mathrm{N}(1)=158.8(3)^{\circ}\right)$. Spectroscopic and elemental microanalysis data for 6-8 are consistent with the bimetallic structures depicted in Scheme 1, and all the species have square planar metal coordination as established for $\mathbf{8}$ in the solid state.

Starting from monosilylated compound $\mathbf{5}$, the multistep pathway to heterobimetallic complexes 10-12 involves lithiation with n-BuLi to afford the corresponding organolithium reagent $\left[\left(\mathrm{Me}_{3} \mathrm{Si}\right)(\mathrm{Li})\left(\mathrm{C}_{2} \mathrm{~N}_{4}\right)\right]$. Transmetalation of the latter with $\left[\mathrm{PtCl}_{2}\left(\mathrm{SEt}_{2}\right)_{2}\right]$ in $\mathrm{THF}$ provides the $\mathrm{Pt}(\mathrm{II})$ complex $\left[\left(\mathrm{Me}_{3} \mathrm{Si}\right)(\mathrm{PtCl})\left(\mathrm{C}_{2} \mathrm{~N}_{4}\right)\right], \mathbf{9}$, in moderate yield (Scheme 1). Complex 9 affords el emental microanalysis and spectroscopic data ${ }^{1} \mathrm{H}$ and ${ }^{13} \mathrm{C}$ NMR) consistent with the proposed structure shown in Scheme $1 .{ }^{11}$ Treatment of $\mathbf{9}$ with a solution of $\mathrm{Pd}(\mathrm{OAC})_{2}$ in a 1:1 mixture of $\mathrm{CH}_{2} \mathrm{Cl}_{2} / \mathrm{MeOH}$, followed by addition of $\mathrm{LiCl}$, results in selective cleavage of the $\mathrm{C}-\mathrm{Si}$ bond mutually trans to the platinum(II) center, affording heterobimetallic platinum(II)-palladium(II) complex [(PdCl)-1-(PtCl)-4- $\left.\left\{\mathrm{C}_{6}\left(\mathrm{CH}_{2} \mathrm{NMe}_{2}\right)_{4}-2,3,5,6\right\}\right], 10$, quantitatively. Complex $\mathbf{1 0}$ has poor solubility characteristics (like 6) and was converted to ionic complexes $\left[(\mathrm{LPd})(\mathrm{LPt})\left(\mathrm{C}_{2} \mathrm{~N}_{4}\right)\right]^{2+}\left(\mathrm{X}^{-}\right)_{2}(\mathrm{~L}=\mathrm{MeCN} ; \mathbf{1 1}, \mathrm{X}=\mathrm{OTf} ; \mathbf{1 2}$, $\left.\mathrm{X}=\mathrm{BPh}_{4}\right)$ which have been characterized by standard spectroscopic and microanalytic methods. ${ }^{11}$

The heterobimetallic ionic triflate complex $\mathbf{1 1}$ is prepared by treatment of $\mathbf{1 0}$ with AgOTf in acetonitrile and shows ${ }^{1} \mathrm{H}$ NMR resonances $\left(\mathrm{CD}_{3} \mathrm{CN}\right.$ solution) of two inequivalent $\mathrm{N}, \mathrm{C}, \mathrm{N}^{\prime}$-coordination moieties, with one set of $\mathrm{CH}_{2} \mathrm{NMe}_{2}$ signals having ${ }^{195} \mathrm{Pt}$ satellites; i.e., the $\mathrm{N}$-donor atom is coordinated to the platinum(II) center. The other set of $\mathrm{CH}_{2} \mathrm{NMe}_{2}$ signals shows no ${ }^{195} \mathrm{Pt}$ satellites and has resonance positions consistent with coordination of these groups to a palladium(II) center. The ${ }^{13} \mathrm{C}$ NMR spectrum of bimetallic complex $\mathbf{1 1}\left(\mathrm{CD}_{3^{-}}\right.$ $\mathrm{CN}$ ) reveals features indicative of the presence of one platinum(II) center and one palladium(II) center in the same molecule; there are two separate resonances for the aromatic carbon atoms bearing the $\mathrm{CH}_{2} \mathrm{NMe}_{2}$ groups,

(11) ${ }^{1} \mathrm{H}$ NMR data of $9\left(\mathrm{CDCl}_{3}, 300 \mathrm{MHz}\right): \delta 4.11\left(\mathrm{~s}, 4 \mathrm{H},{ }^{3} \mathrm{Pt}-\mathrm{H}=\right.$ $\left.45.3 \mathrm{~Hz} \mathrm{NCH}_{2}\right), 3.37\left(\mathrm{~s}, 4 \mathrm{H}, \mathrm{NCH}_{2}\right), 3.04(\mathrm{~s}, 12 \mathrm{H}, 3 \mathrm{Jt}-\mathrm{H}=35.9 \mathrm{~Hz}$, $\left.\mathrm{NMe}_{2}\right), 2.01\left(\mathrm{~s}, 12 \mathrm{H}, \mathrm{NMe}_{2}\right), 0.31\left(\mathrm{~s}, 9 \mathrm{H}, \mathrm{SiMe}_{3}\right)$. ${ }^{13 \mathrm{C}} \mathrm{NMR}$ data of 9 $\left(\mathrm{CDCl}_{3}, 75 \mathrm{MHz}\right): \delta 147.0\left(\mathrm{C}-\mathrm{Pt},{ }^{1} \mathrm{jt}-\mathrm{C}=1000 \mathrm{~Hz}\right), 141.7(3 \mathrm{jt}-\mathrm{C}=$ $75 \mathrm{~Hz}), 139.1(2 \mathrm{pt}-\mathrm{C}=44 \mathrm{~Hz}), 133.5\left(\mathrm{C}_{\text {aryl }}-\mathrm{SiMe}_{3}\right), 77.7\left(\mathrm{NCH}_{2},{ }^{2} \mathrm{~J} \mathrm{Pt}-\mathrm{C}\right.$ $=60 \mathrm{~Hz}), 62.6\left(\mathrm{NCH}_{2}\right), 54.4\left(\mathrm{NMe}_{2}, 2 \mathrm{~J} \mathrm{Pt}-\mathrm{C}=13 \mathrm{~Hz}\right), 44.6\left(\mathrm{NMe}_{2}\right), 4.2$ (SiMes). ${ }^{1} \mathrm{H}$ NMR data of $\mathbf{1 1}\left(\mathrm{CD}_{3} \mathrm{CN}+10 \% \mathrm{D}_{2} \mathrm{O}, 200 \mathrm{MHz}\right): \delta 4.08$ $\left(\mathrm{s}, 4 \mathrm{H}\right.$, 3 $\left.\mathrm{pt}_{-\mathrm{H}}=46.5 \mathrm{~Hz}, \mathrm{NCH}_{2}\right), 3.86\left(\mathrm{~s}, 4 \mathrm{H}, \mathrm{NCH}_{2}\right), 2.96(\mathrm{~s}, 12 \mathrm{H}$ 3. $\left.\mathrm{Pt}-\mathrm{H}=39.0 \mathrm{~Hz}, \mathrm{NMe}_{2}\right), 2.80\left(\mathrm{~s}, 12 \mathrm{H}, \mathrm{NMe}_{2}\right) .{ }^{13} \mathrm{C} \mathrm{NMR}$ data of 11 $\left(\mathrm{CD}_{3} \mathrm{CN}+10 \% \mathrm{D}_{2} \mathrm{O}, 50 \mathrm{MHz}\right): \delta 152.7(\mathrm{C}-\mathrm{Pd}), 141.2\left(\mathrm{C}-\mathrm{Pt}{ }^{1}{ }^{\mathrm{J}} \mathrm{Pt}-\mathrm{C}\right.$ not observed), $138.9\left({ }^{3} \mathrm{jt}-\mathrm{C}=82 \mathrm{~Hz}\right), 138.8\left({ }^{2} \mathrm{j} \mathrm{pt}-\mathrm{C}=43 \mathrm{~Hz}\right), 75.7$ $\left(\mathrm{NCH}_{2},{ }^{2} \mathrm{JPt}-\mathrm{C}=64 \mathrm{~Hz}\right), 72.8\left(\mathrm{NCH}_{2},{ }^{4} \mathrm{~J} \mathrm{Pt}-\mathrm{C}=11 \mathrm{~Hz}\right), 55.1\left(\mathrm{NMe}_{2},{ }^{2} \mathrm{Pt}-\mathrm{C}\right.$ $=16 \mathrm{~Hz}), 53.4\left(\mathrm{NMe}_{2}\right)$. and each has only one set of ${ }^{195} \mathrm{Pt}$ satellites. In a symmetrical doubly platinated aryl ring the carbon atoms bearing the $\mathrm{CH}_{2} \mathrm{NMe}_{2}$ groups would give rise to a single resonance with two sets of satellites, i.e. ${ }^{2} \mathrm{Jt}-\mathrm{C}$ and ${ }^{3} \mathrm{Pt}-\mathrm{C} .{ }^{11}$ The anal ogous tetraphenyl borate species $\mathbf{1 2}$ was prepared by precipitation from a solution of $\mathbf{1 1}$ treated with $\mathrm{NaBPh}_{4}$. Elemental microanalysis (12) and spectroscopic data (11) are in agreement with the proposed structures (Scheme 1).

The novel neutral and ionic bimetallic compounds are air and moisture stable, and an interesting aspect of the ionic triflate compl exes $\mathbf{7}(\mathrm{Pd} / \mathrm{Pd})$ and $\mathbf{1 1}(\mathrm{Pd} / \mathrm{Pt})$ lies in the potential offered by the lability of the MeCN ligands for further development of new organometallic materials. Preliminary experiments show that on the ${ }^{1} \mathrm{H}$ NMR time scale the coordinated $\mathrm{CH}_{3} \mathrm{CN}$ is labile and exchanges rapidly with the solvent $\left(\mathrm{CD}_{3} \mathrm{CN}\right)$ and that addition of pyridine results in the formation of a dicationic complex in which both metal centers are coordinated by pyridine. These experiments illustrate the real possibility of using cationic monophenylene bridged homo- and heterobimetallic complexes $\mathbf{7}$ and $\mathbf{1 1}$ as building blocks for air- and moisture-stable (directional) organometallic polymers ${ }^{12}$ when additional bridging ligands such as 4,4'-bi pyridine or pyrazine are used. This approach is currently being studied as species such as $\mathbf{7}$ and $\mathbf{1 1}$ have potential for electronic $M-M^{\prime}$ communication and could possibly be employed as structural elements in new materials or bimetallic catalyst systems.

Acknowledgment. This work was supported in part (P.S. and A.L.S.) by the Netherlands Foundation for Chemical Research (SON) with financial aid from the Netherlands Organization for Scientific Research (NWO). We also thank Prof. Dr. A. J . Canty for critical comments.

Supporting Information Available: Tables of X-ray parameters, all positional parameters, thermal parameters, bond lengths, and bond angles for 8 (8 pages). Ordering information is given on any current masthead page. Atomic coordinates, bond lengths and angles, and thermal parameters have been deposited at the Cambridge Crystallographic Data Centre; see the Notice to Authors, issue no. 1.

\section{OM960943Y}

(12) (a) Hagihara, N.; Sonogashira, K.; Takahashi, S. Adv. Polym. Sci. 1981, 41, 149. (b) Shears, J. E.; Carraher, J r., C. E.; Pittmann, C. U., J r. Metal-Containing Polymer Systems; Plenum: New York, 1985. 